\title{
Pathogenesis of Ischemic Stroke: Role of Epigenetic Mechanisms
}

\author{
Rosita Stanzione ${ }^{1, *}$, Maria Cotugno ${ }^{1}$, Franca Bianchi ${ }^{1}$, Simona Marchitti ${ }^{1}$, Maurizio Forte ${ }^{1}$, \\ Massimo Volpe ${ }^{1,2}$ and Speranza Rubattu ${ }^{1,2}$ \\ 1 IRCCS Neuromed, Via Atinense, 18, 86077 Pozzilli IS, Italy; maria.cotugno@neuromed.it (M.C.); \\ franca.bianchi@neuromed.it (F.B.); simona.marchitti@neuromed.it (S.M.); maurizio.forte@neuromed.it (M.F.); \\ massimo.volpe@uniroma1.it (M.V.); rubattu.speranza@neuromed.it (S.R.) \\ 2 Department of Clinical and Molecular Medicine, School of Medicine and Psychology, Sapienza University of \\ Rome, 00189 Rome, Italy \\ * Correspondence: stanzione@neuromed.it; Tel.: +86-5915224
}

Received: 29 November 2019; Accepted: 9 January 2020; Published: 13 January 2020

check for updates

\begin{abstract}
Epigenetics is the branch of molecular biology that studies modifications able to change gene expression without altering the DNA sequence. Epigenetic modulations include DNA methylation, histone modifications, and noncoding RNAs. These gene modifications are heritable and modifiable and can be triggered by lifestyle and nutritional factors. In recent years, epigenetic changes have been associated with the pathogenesis of several diseases such as diabetes, obesity, renal pathology, and different types of cancer. They have also been related with the pathogenesis of cardiovascular diseases including ischemic stroke. Importantly, since epigenetic modifications are reversible processes they could assist with the development of new therapeutic approaches for the treatment of human diseases. In the present review article, we aim to collect the most recent evidence concerning the impact of epigenetic modifications on the pathogenesis of ischemic stroke in both animal models and humans.
\end{abstract}

Keywords: ischemic stroke; epigenetic; DNA methylation; histone modification; miRNA; lncRNA

\section{Introduction}

Ischemic stroke (IS) represents the second global cause of death, after ischemic heart disease, and the most common cause of disability worldwide [1-3]. IS occurs when the occlusion of a cerebral artery by an embolus or a thrombus produces a reduction of blood flow and oxygen to the brain [4]. This phenomenon, when persistent, contributes to irreversible brain damage due to neuronal cell death. The increase of both inflammation and oxidative stress is another common feature of IS, and can be interpreted either as a cause or as a consequence [5]. Stroke is a heterogeneous, multifactorial disease resulting from the interaction between numerous environmental and genetic risk factors [6,7]. Several case-control association studies revealed the contributory role of single nucleotide polymorphisms (SNPs) belonging to key hormonal and molecular systems including: the renin-angiotensin-aldosterone system (RAAS) [8], the natriuretic peptides family [9], the hemostasis and coagulation cascade [10,11], the lipoprotein metabolism [12], inflammation [13,14], homocysteine metabolism [15]. Our group has demonstrated that genes encoding proteins of the mitochondrial electron transport chain are key elements to guarantee correct mitochondrial function, cell viability and protection from stroke occurrence [16-20]. Genome-wide association studies confirmed the existence of several variants belonging to different genes associated with IS and their specific subtypes, such as paired-like homeodomain transcription factor 2 (PITX2) and Zinc Finger Homeobox 3 (ZFHX3) in 
the cardioembolic stroke [21], histone deacetylase 9 (HDAC9), and cyclin dependent kinase inhibitor $(C D K N)$ in the large-vessel stroke subtype [22].

Although several studies have investigated the molecular and genetic mechanisms underlying the pathogenesis of stroke, additional mechanisms still remain to be elucidated. Recently, increased evidence supports the involvement of epigenetic alterations in the pathogenesis of cardiovascular diseases in both humans and animal models [23,24], and particularly in the susceptibility to stroke.

Epigenetic modifications alter gene expression without changing the DNA sequence. Some of them are stable and inherited by subsequent generations [25]. In several cases, the epigenetic changes are dynamic and responsive to environmental stimuli. Epigenetic mechanisms can regulate different physiological processes that occur in a living organism, including cellular proliferation and differentiation. A deeper knowledge of the epigenetic modifications related to stroke and to its risk factors could provide the basis for the development of innovative approaches in the prevention and treatment of this disabling disease.

In this review article, we will describe the different types of epigenetic mechanisms and their involvement in the pathogenesis of IS (Figure 1).

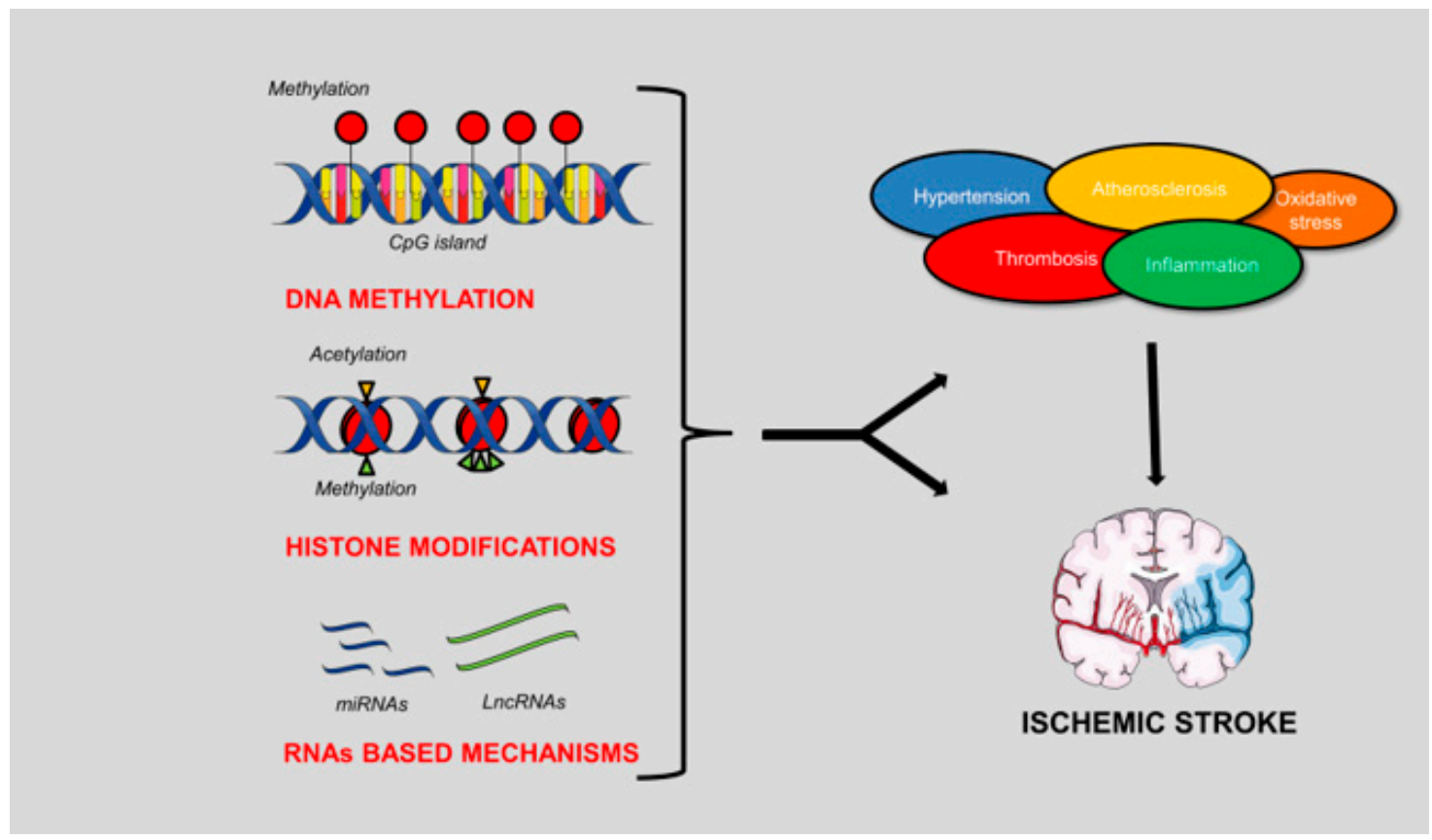

Figure 1. Schematic representation of the epigenetic mechanisms involved in the pathogenesis of ischemic stroke (IS). DNA methylation, histone modifications and RNA-based mechanisms can contribute either indirectly or directly to the development of the brain ischemic damage. In fact, both genes involved in the conditions predisposing to IS and genes directly involved in stroke pathogenesis are modulated by these mechanisms. The figure was made in part using tools provided by Servier Medical Arts.

\section{Overview of Epigenetic Mechanisms of Gene Regulation}

Epigenetics includes the processes that modify gene expression without changing the DNA sequence $[26,27]$. The main epigenetic mechanisms include DNA methylation, histone modifications, and RNA-based mechanisms.

DNA methylation is a reversible modification which usually decreases gene transcription through a chemically stable modification carried out by DNA methyltransferase (DNMT) associated with the addition of a methyl group $\left(-\mathrm{CH}_{3}\right)$ in the $5^{\prime}$ position of cytosine in the gene promoter. This modification prevents the interaction between transcription factors with their specific binding sites [28]. 
Histone modifications include acetylation and methylation of lysine residues in the terminal tail of histones $\mathrm{H} 3$ and H4. These changes are performed by histone acetyltransferases (HATs) and histone methyl transferases (HMTs), respectively [29,30]. These modifications modulate histone-DNA interactions by influencing the chromatin structure, thereby directing the accessibility of transcriptional regulators to DNA-binding elements. Histone acetylation, catalyzed by HATs, generally increases gene expression whereas histone deacetylation, through histone deacetylases (HDACs), inhibits gene expression. Histone methylation can either activate or inhibit the expression of genes and it usually involves the arginine residues [31].

Some interesting RNA-based mechanisms are those involving microRNAs (miRNAs) or long noncoding RNAs (LncRNAs). miRNAs are a group of small single-stranded noncoding RNAs of 18 to 22 nucleotides that have been identified in many organisms. miRNAs act as post-transcriptional regulators of gene expression. Once maturated, miRNAs interact with the $3^{\prime}$-untraslated region of a mRNA target (3'-UTR). Depending on the degree of complementarity between the miRNA and its target, gene silencing may occur either by mRNA degradation or by inhibition of translation. A single miRNA can regulate multiple gene targets [32]. miRNAs are involved in crucial biological processes including cell proliferation and differentiation, apoptosis, fat metabolism, and hematopoiesis [33,34]. They can be dysregulated in several pathological conditions including cardiovascular diseases [35].

In recent years, the interest in LncRNAs has also increased. LncRNAs are transcripts longer than 200 nucleotides, located within either the intergenic stretches or the overlapping antisense transcripts of protein coding genes. LncRNAs can regulate the expression of target genes by both transcriptional and post-transcriptional mechanisms [36]. It has been reported that LncRNAs are regulators of vascular function and their dysregulation contributes to cardiovascular diseases $[37,38]$.

\section{DNA Methylation in IS}

The role of promoter DNA methylation in the pathogenesis of IS has been well investigated in recent years (Table 1) [39,40]. In general, the global level of DNA methylation is higher in animal models of IS and is associated with higher activity of DNMT in the brain. In fact, pharmacological inhibition of DNMT was shown to decrease DNA methylation, to reduce the infarct size and cerebral ischemic damage in the middle cerebral artery occlusion (MCAO) rat model [41-43].

In the same model, a decreased DNA methylation level of Na-K-Cl cotransporter 1 (NKCC1), a membrane protein involved in the active transport of sodium, potassium, and chloride, was associated with re-expression of brain NKCC1 mRNA and protein after neuronal injury [44]. Further studies are needed to define the specific role of NKCC1 in IS.

It is well established that disorders of the coagulation cascade predisposing to IS can cause either hemorrhagic or thrombotic lesions. For example, Hu et al. found that thrombospondin 1 (THBS1), an angiostatic factor also involved in platelet aggregation, was hypermethylated in an in vitro model of ischemia. This finding suggests that THBS1 may contribute to post-ischemic angiogenesis, a mechanism needed to repair brain damage following ischemia [45].

In humans, high levels of plasma homocysteine are known to be an independent risk factor for several vascular disorders including atherosclerosis, coronary artery disease, and stroke [46]. The metabolism of homocysteine is regulated by dietary factors, such as methionine and vitamins B, and by different enzymes, such as methylentetrahydrofolate reductase (MTHFR), cystathionine-beta-synthase (CBS) and methionine synthase MS (MS). CBS is the main enzyme involved in the conversion of homocysteine to cysteine. Dietary deficiencies and alterations in homocysteine metabolism are associated with higher stroke occurrence. Recently, Wang et al. described DNA hypermethylation in the CBS promoter and its association with increased risk of stroke in human populations. Hypermethylation of $C B S$ leads to low enzyme activity, plasma homocysteine accumulation, and increased susceptibility to stroke [47]. High levels of plasma homocysteine are also associated with DNA hypermethylation of thrombomodulin (TM) in patients with IS. TM is an integral membrane protein expressed on the surface of endothelial cells. It possesses anticoagulant 
properties by acting as a thrombin receptor. The soluble form of TM plays an important role in the regulation of intravascular coagulation. For this reason, TM exerts a protective effect against cerebral ischemia. In fact, DNA hypermethylation of TM promoter was found to correlate with high level of homocysteine, with increased endothelial damage and increased risk of IS [48].

Epidemiological studies have shown the role of dyslipidemia as an important risk factor for IS [49]. In this regard, elevated levels of both triglycerides and low-density lipoprotein (LDL)-cholesterol were associated with an increased risk of stroke, whereas high-density lipoprotein (HDL) cholesterol levels showed an inverse correlation [50-53]. Several studies suggest the role of apolipoprotein E (ApoE) in IS. ApoE is a plasma lipoprotein involved in lipid metabolism that interacts with the LDL receptor [54]. Polymorphisms of the ApoE gene $(A P O E-\varepsilon)$ were shown to be frequent in subjects with atherosclerosis [54], Alzheimer's disease [55], and IS [56]. A recent study also demonstrated the association between the methylation status of the $A p o E$ gene promoter and atherosclerotic cerebral infarction (ACI), a common form of stroke. Specifically, DNA hypermethylation of ApoE promoter repressed the expression of the gene. The latter correlated with lower levels of both HDL cholesterol and folate, and with higher levels of homocysteine. The hypermethylation of ApoE can be prevented by reducing homocysteine level with folate administration [57].

Higher level of DNA methylation of cyclin dependent kinase inhibitor $2 \mathrm{~B}(C D K N 2 B)$, a gene involved in the pathogenesis of both atherosclerosis and arterial calcification, was associated with increased susceptibility to calcification of the arteries in patients with IS [58].

Finally, the expression of inflammatory mediators is also influenced by epigenetic mechanisms. Vascular cell adhesion protein 1 level (VCAM-1) represents a marker of cardiovascular diseases since it is rapidly expressed in pro-atherosclerotic conditions $[59,60]$. Baccarelli et al. showed that the hypomethylation of long interspersed nucleotide elements (LINE-1) was associated with increased levels of VCAM-1 in elderly individuals. In the same study, the authors reported that the association between LINE-1 hypomethylation and VCAM-1 expression was significant only in subjects without prevalent ischemic heart disease or stroke. Instead, no correlation was found in patients with heart disease and stroke. The latter evidence suggests that the association between LINE hypomethylation and VCAM-1 expression may be considered as an early event in the etiology of cardiovascular and cerebrovascular diseases [61]. The hypomethylation of TNF receptor-associated factor 3 (TRAF3) and of protein phosphatase 1A (PPM1A) is also related to increased stroke occurrence in patients treated with antiplatelet drugs [62,63].

Table 1. DNA methylation in IS.

\begin{tabular}{|c|c|c|c|}
\hline Study Model & Condition/Effects & Outcomes & References \\
\hline MCAO rat & $\begin{array}{l}\text { Pharmacological inhibition of } \\
\text { DNMT }\end{array}$ & $\begin{array}{c}\downarrow_{\text {Infarct size }} \\
\downarrow \text { Cerebral ischemic damage }\end{array}$ & [41-43] \\
\hline MCAO rat & $\begin{array}{l}\text { Increased demethylation of } \\
\text { NKCC1 }\end{array}$ & $\uparrow$ Cerebral ischemic injury & [44] \\
\hline $\begin{array}{l}\text { Rat endothelial cells } \\
\text { under oxygen-glucose } \\
\text { deprivation (OGD) }\end{array}$ & Hypermethylation of THBS1 & $\uparrow$ Angiogenesis & [45] \\
\hline $\begin{array}{l}\text { Hypertensive and stroke } \\
\text { patients }\end{array}$ & Hypermethylation of $C B S$ & $\begin{array}{l}\uparrow \text { Homocysteinemia } \\
\uparrow_{\text {stroke occurrence }}\end{array}$ & {$[47]$} \\
\hline Stroke patients & Hypermethylation of TM & $\begin{array}{l}\uparrow \text { Vascular endothelial damage } \\
\qquad \uparrow \text { Risk of IS }\end{array}$ & [48] \\
\hline
\end{tabular}


Table 1. Cont.

\begin{tabular}{|c|c|c|c|}
\hline Study Model & Condition/Effects & Outcomes & References \\
\hline $\begin{array}{l}\text { Meta-analysis study of } \\
\text { stroke patients } \\
\text { Stroke patients }\end{array}$ & Hypermethylation of $A p o E$ & $\begin{array}{c}\uparrow \text { Lipoprotein accumulation } \\
\uparrow \text { Atherosclerotic cerebral } \\
\text { infarction }\end{array}$ & {$[56,57]$} \\
\hline Stroke patients & Hypermethylation of $C D K N 2 B$ & $\uparrow$ Aortic arch calcification & {$[58]$} \\
\hline Elderly patients & Hypomethylation of LINE-1 & $\uparrow$ VCAM-1 level & {$[61]$} \\
\hline $\begin{array}{l}\text { Stroke patients receiving } \\
\text { antiplatelet drugs }\end{array}$ & $\begin{array}{l}\text { Hypomethylation of TRAF3 } \\
\text { and PPM1A }\end{array}$ & $\uparrow$ Stroke occurrence & {$[62,63]$} \\
\hline
\end{tabular}

\section{Histone Modifications in IS}

Studies in both humans and animal models highlighted the role of histone modifications in chromatin remodeling and their involvement in various brain disorders including IS [64]. Several groups identified a general decrease of histone $\mathrm{H} 3$ [65] and $\mathrm{H} 4$ [66] acetylation level in animal models of stroke, which was associated with severe brain damage. Since epigenetic changes can be reversed, the administration of HDAC inhibitors was reported to be a valid approach to decrease brain injury. In the MCAO models, the administration of valproic acid or sodium butyrate, two widely used HDAC inhibitors, was found to either preserve or restore the normal acetylation level of $\mathrm{H} 3$ and $\mathrm{H} 4$ histones. These effects contributed to a substantial reduction of infarct volume and to the improvement of brain damage. Furthermore, a significant increase of Hsp70, a prosurvival heat shock protein, and a parallel decrease of proapoptotic protein caspase-3 were reported in MCAO models treated with HDAC inhibitors [67]. Recently, a relationship between HDAC4 and IS was highlighted. Kong et al. described that HDAC4 was reduced in neuronal cells isolated from MCAO rat model and subjected to oxygen-glucose deprivation (OGD) [68]. Low levels of HDAC4 were associated with alterations in cell proliferation and angiogenesis [69] and with loss of integrity of the blood-brain barrier (BBB) [70]. Exogenous administration of HDAC inhibitors rescued $\mathrm{H} 4$ acetylation level, restored BBB integrity, and reduced infarct volume in the MCAO rat [71].

HDAC inhibition exerts a protective effect also against inflammatory reactions in IS [72]. Indeed, in primary microglial cells isolated from the MCAO mouse model, HDAC inhibition with sodium butyrate was reported to increase the acetylation of lysine 9 within $\mathrm{H} 3$ histone (H3K9ac), along with the downregulation of different proinflammatory mediators, such as interleukin 6 (IL-6), inducible nitric oxide synthase (iNOS), tumor necrosis factor- $\alpha$ (TNF- $\alpha$ ), and with a parallel upregulation of the anti-inflammatory mediator interleukin 10 (IL-10) [40].

Despite promising results obtained in preclinical studies, the use of HDAC inhibitors have not yet provided satisfactory results in patients with IS. First of all, most specific inhibitors of HDAC are not permeable to the BBB; secondly, unspecific HDAC inhibitors were associated with several adverse effects such as weight loss, taste disturbances, electrolyte changes, and cardiac arrhythmias in stroke Phase I/II clinical studies [73]. However, Brookes et al. reported the protective effects of sodium valproate, a nonspecific inhibitor of HDAC9, in patients with previous stroke or transient ischemic attack. They found that the administration of sodium valproate strongly reduced the risk of recurrent stroke [74].

\section{RNA-Based Mechanisms in IS}

Human and animal studies revealed alterations of miRNA levels in several pathological conditions, such as hypertension, dyslipidemia, atherosclerosis, and inflammation, that predispose to IS [75]. 
In addition, modifications of miRNA levels were identified in different stages of stroke suggesting their potential use for diagnostic, prognostic, and therapeutic purposes [76-78].

Studies performed in the MCAO rat model found a significant increase of both cerebral and plasma levels of miR-124, reaching a peak at $24 \mathrm{~h}$ after stroke development, compared to the control group. These results suggest that the plasma level of miR-124 can be used to monitor brain ischemic damage [79]. In the same rat model, Dharap et al. studied the brain profile of 238 miRNAs and found several up and downregulated miRNAs at different times of reperfusion. A bioinformatic analysis revealed that the deregulated miRNAs target the mRNAs of several genes involved in IS. Among them, there are genes belonging to the inflammatory pathway [interleukin $1 \beta$ (IL1 $\beta$ ) and IL6, intercellular adhesion molecule 1 (ICAM1), cyclooxygenase 2 (COX2)], to neuroprotection [heat shock protein 27 (HSP27), peripheral-type benzodiazepine receptor (PTBR), manganese superoxide dismutase $(\mathrm{Mn}$-SOD), insulin-like growth factor binding protein 3 (IGF-BP3)], to transcription regulation [nuclear factor kappa-light-chain enhancer of activated B cells (NF- $k B$ ), hypoxia inducible factor 1 (HIF1), early growth inhibitor 1 (Egr1), activating transcription factor 3 (ATF3)] [80]. These processes collectively play a fundamental role during post-ischemic brain remodeling.

In the stroke prone spontaneously hypertensive rat (SHRSP), a suitable rat model of human stroke [81], a reduced miR-122 level behaves as a marker of stroke and is associated with reduced endothelial integrity, increased apoptosis and inflammation [82]. In the same rat model, the brain expression of uncoupling protein 2 (UCP2) is regulated by miR-503. UCP2 is a mitochondrial anion carrier protein that exerts an antioxidant effect in several tissues [83]. High-salt diet fed SHRSP showed a significant upregulation of brain miR-503 level compared to the control strain, the stroke resistant spontaneously hypertensive rat (SHRSR), with a consequent decrease of brain UCP2 expression and increased stroke occurrence [17].

Recently, the association between microRNA-21 and stroke was also investigated. miR-21 is upregulated in several diseases such as diabetes [84], hypertension [85], other cardiovascular diseases, and cancer [86]. Several reports suggest that mir-21 regulates cell proliferation, apoptosis, invasion, and migration by targeting genes including phosphate and tensin homolog (PTEN), reversion inducing cysteine rich protein with kazal motifs (RECK), B-cell lymphoma 2 (Bcl-2), and programmed cell death 4 (PDCA4) [87]. The level of miR-21 was found to be increased in the MCAO rat model and in stroke patients. In the MCAO model, an increase of miR-21 level was related to the downregulation of Fas Ligand (Faslg), a member of the tumor necrosis factor super-family and a predicted target gene of miR-21. Faslg can trigger apoptosis by binding to Fas cell surface death receptor (FAS). Faslg is an important cell death regulator and its downregulation exerts a protective effect in neuronal cells [88]. Plasma levels of miR-21 were also found to be significantly upregulated in patients with IS but not in patients with transient ischemic attack. It is likely that miR-21 may represent a discriminative biomarker for stroke subtypes [89].

Studies performed in young stroke patients also demonstrated a specific profile of miRNAs expression. The deregulated miRNAs included mostly those regulating angiogenesis, neuronal, and vascular functions [90].

Recently, miR-335 has also emerged as an important biomarker in IS. A low plasma level of miR-335 was found in patients with acute IS and it correlated with the increase of plasma calmodulin (CaM), a direct target of miR-335 [91]. Calmodulin is a protein involved in many calcium-mediated processes and plays an important role in the mechanisms of ischemic brain injury and of stroke progression [92]. These results support the miR-335 as a useful noninvasive circulating biomarker of stroke.

Chen et al. studied the relationship between miR-211 and angiopoietin1 (ANG-PT1) in a large cohort of IS patients [93]. ANG-PT1 is a protein involved in endothelial cell survival and angiogenesis [94,95] with a binding site for mir-211 localized at 3'-UTR. This binding site matches with a gene polymorphism (rs2507800 A > T). Carriers of the A allele (wild-type) bind normally the miR-211 and show a downregulation of ANG-PT1 level. On the other hand, the presence of the mutant 
$\mathrm{T}$ allele reduces the miR-211 binding with a significant increase of ANG-PT1 level, which in turn contributes to vascular damage and increased stroke susceptibility [93].

Our group demonstrated that the T2238C variant of the atrial natriuretic peptide (ANP) gene, a nonmodifiable risk factor for cardiovascular diseases including stroke, modulates ApoE level through miR-199 in vitro. The miR-199 up-regulation induced by C2238/ $\alpha$ ANP, and not by the wild type ANP, produced a downregulation of ApoE associated with decreased cell viability and increased apoptosis, necrosis, and inflammation in human vascular smooth muscle cells [96]. These results support the growing importance of miRNAs in the pathogenesis of stroke.

In recent years, the interest on LncRNAs has also increased. LncRNAs act as important regulatory factors in IS by modulating cell survival, inflammation, and angiogenesis. New technologies allowed the discovery of more than 200 LncRNAs differentially expressed in the brain of animal models and in the blood of IS patients [97,98]. For example, the role of LncRNAs ANRIL (antisense non-coding RNA in the INK4 Locus), MALAT1 (metastasis associated lung adenocarcinoma transcript 1), MEG3 (maternally expressed 3) and TUG1 (taurine up-regulated 1) was investigated in preclinical models of IS $[99,100]$. Expression of ANRIL was found significantly increased in the brain of rat models of stroke where it promoted angiogenesis through the activation of vascular endothelial growth factor (VEGF) and of its receptor ferritin light chain-1 (FLT-1). ANRIL was found to regulate also inflammation through NF-kB signaling [101].

MALAT1, MEG3, and TUG1 are LncRNAs involved in the regulation of cell proliferation, inflammation, and apoptosis. Abnormalities of the regulation of these processes are involved in the pathogenesis of IS through the causation of neuronal injury. Recently, MALAT1 was found to be significantly increased in the brain of the MCAO mouse model as an adaptive response following the ischemic insult. Consistently, MALAT1 knockout mice undergoing MCAO showed an exacerbated brain injury, along with the increase of proapoptotic and inflammatory factors. The latter evidence suggests that MALAT1 plays a protective role in IS [102].

The LcnRNA MEG3 was shown to be overexpressed in the brain of the MCAO mice, along with the upregulation of p53 and of 12/15-Lipoxygenase (12/15-LOX), two activators of cell death [103,104]. Specifically, MEG3 was found to interact with p53 during ischemia, allowing the activation of neuronal cell apoptosis. The inhibition of MEG3 interaction with p53 suppressed neuronal apoptosis and reduced infarction volume [103]. In a separate study, MEG3 upregulation was associated with the increase of 12/15-LOX and with increased neuronal cell death [105]. Overall, these findings suggest that MEG3 exerts deleterious effects during brain ischemia.

The LncRNA TUG1 also regulates apoptosis in different cell types [106,107]. Regarding its role in IS, Chen et al. reported TUG1 overexpression in the brain of the MCAO rat model. In the same study, TUG1 was found to bind miR-9 in primary neurons subjected to oxygen-glucose deprivation (OGD), with the consequent decrease of its activity. miR-9 acts as an anti-apoptotic factor by targeting the pro-apoptotic protein Bim-1. Inhibition of TUG1 rescued neuronal survival during OGD by boosting miR-9 activity [108].

In humans, different studies have characterized the profile of approximately 3000 LncRNAs by using several technologies. The expression level of hundreds of LncRNAs was altered in peripheral blood of patients with IS. These results suggest that lncRNAs may have a potential role in stroke development and progression [109].

\section{Conclusions}

Several studies performed in animal models of stroke and in human patients contributed to elucidate the complex genetic and molecular mechanisms involved in the pathogenesis of IS. The epigenetic mechanisms are emerging as novel, fundamental factors involved in the regulation of the expression of stroke-related genes. Epigenetic modifications, differently from change in gene sequence, are reversible. Pharmacological inhibitors of DNA methyltransferases, histone acetyltransferases, and histone deacetylases, the main enzymes involved in epigenetic modifications, can be used to 
change the expression level of a gene of interest. Interestingly, some of these inhibitors are already used in animal models of stroke [110] and they are available in clinical practice for the treatment of hematological diseases [111]. The antagomirs administration induces a neuroprotective effect in animal models of stroke [112]. This approach appears to be promising in order to inhibit miRNAs for therapeutic purposes [113].

Although the development of molecules regulating the epigenetic processes may result difficult and expensive, this new approach could reveal very useful for the development of novel pharmacological therapies against IS in the future.

Author Contributions: R.S. performed the literature search and prepared the article draft. M.C., F.B., S.M. contributed to the literature search. M.F. contributed to the article writing and figure preparation. S.R. and M.V. provided article supervision and editing. All authors have read and agree to the published version of the manuscript.

Funding: This work was supported by a grant from the Italian Ministry of Health and the " 5 per mille" grant.

Conflicts of Interest: The authors declare no conflicts of interest.

\section{References}

1. Hajat, C.; Heuschmann, P.U.; Coshall, C.; Padayachee, S.; Chambers, J.; Rudd, A.G.; Wolfe, C.D. Incidence of aetiological subtypes of stroke in a multi-ethnic population based study: The South London Stroke Register. J. Neurol. Neurosurg. Psychiatry 2011, 82, 527-533. [CrossRef]

2. Favate, A.S.; Younger, D.S. Epidemiology of Ischemic Stroke. Neurol. Clin. 2016, 34, 967-980. [CrossRef] [PubMed]

3. Benjamin, E.J.; Muntner, P.; Alonso, A.; Bittencourt, M.S.; Callaway, C.W.; Carson, A.P.; Chamberlain, A.M.; Chang, A.R.; Cheng, S.; Das, S.R.; et al. Heart Disease and Stroke Statistics-2019 Update: A Report From the American Heart Association. Circulation 2019, 139, e56-e528. [CrossRef]

4. Raichle, M.E. The pathophysiology of brain ischemia. Ann. Neurol. 1983, 13, 2-10. [CrossRef] [PubMed]

5. Chehaibi, K.; Trabelsi, I.; Mahdouani, K.; Slimane, M.N. Correlation of Oxidative Stress Parameters and Inflammatory Markers in Ischemic Stroke Patients. J. Stroke Cerebrovasc. Dis. 2016, 25, 2585-2593. [CrossRef] [PubMed]

6. Rubattu, S.; Giliberti, R.; Volpe, M. Etiology and pathophysiology of stroke as a complex trait. Am. J. Hypertens. 2000, 13, 1139-1148. [CrossRef]

7. Hassan, A.; Markus, H.S. Genetics and ischaemic stroke. Brain 2000, 123 Pt 9, 1784-1812. [CrossRef]

8. Rubattu, S.; Di Angelantonio, E.; Stanzione, R.; Zanda, B.; Evangelista, A.; Pirisi, A.; De Paolis, P.; Cota, L.; Brunetti, E.; Volpe, M. Gene polymorphisms of the renin-angiotensin-aldosterone system and the risk of ischemic stroke: A role of the A1166C/AT1 gene variant. J. Hypertens. 2004, 22, 2129-2134. [CrossRef]

9. Rubattu, S.; Stanzione, R.; Di Angelantonio, E.; Zanda, B.; Evangelista, A.; Tarasi, D.; Gigante, B.; Pirisi, A.; Brunetti, E.; Volpe, M. Atrial natriuretic peptide gene polymorphisms and risk of ischemic stroke in humans. Stroke 2004, 35, 814-818. [CrossRef]

10. Catto, A.J. Genetic aspects of the hemostatic system in cerebrovascular disease. Neurology 2001, 57 (Suppl. 2), S24-S30. [CrossRef]

11. Rubattu, S.; Di Angelantonio, E.; Nitsch, D.; Gigante, B.; Zanda, B.; Stanzione, R.; Evangelista, A.; Pirisi, A.; Rosati, G.; Volpe, M. Polymorphisms in prothrombotic genes and their impact on ischemic stroke in a Sardinian population. Thromb. Haemost. 2005, 93, 1095-1100. [CrossRef] [PubMed]

12. Bersano, A.; Ballabio, E.; Bresolin, N.; Candelise, L. Genetic polymorphisms for the study of multifactorial stroke. Hum. Mutat. 2008, 29, 776-795. [CrossRef] [PubMed]

13. Picascia, A.; Grimaldi, V.; Iannone, C.; Soricelli, A.; Napoli, C. Innate and adaptive immune response in stroke: Focus on epigenetic regulation. J. Neuroimmunol. 2015, 289, 111-120. [CrossRef] [PubMed]

14. Flex, A.; Gaetani, E.; Papaleo, P.; Straface, G.; Proia, A.S.; Pecorini, G.; Tondi, P.; Pola, P.; Pola, R. Proinflammatory genetic profiles in subjects with history of ischemic stroke. Stroke 2004, 35, 2270-2275. [CrossRef] 
15. Cotlarciuc, I.; Malik, R.; Holliday, E.G.; Ahmadi, K.R.; Pare, G.; Psaty, B.M.; Fornage, M.; Hasan, N.; Rinne, P.E.; Ikram, M.A.; et al. Effect of genetic variants associated with plasma homocysteine levels on stroke risk. Stroke 2014, 45, 1920-1924. [CrossRef]

16. Di Castro, S.; Scarpino, S.; Marchitti, S.; Bianchi, F.; Stanzione, R.; Cotugno, M.; Sironi, L.; Gelosa, P.; Duranti, E.; Ruco, L.; et al. Differential modulation of uncoupling protein 2 in kidneys of stroke-prone spontaneously hypertensive rats under high-salt/low-potassium diet. Hypertension 2013, 61, 534-541. [CrossRef]

17. Rubattu, S.; Stanzione, R.; Bianchi, F.; Cotugno, M.; Forte, M.; Della Ragione, F.; Fioriniello, S.; D’Esposito, M.; Marchitti, S.; Madonna, M.; et al. Reduced brain UCP2 expression mediated by microRNA-503 contributes to increased stroke susceptibility in the high-salt fed stroke-prone spontaneously hypertensive rat. Cell Death Dis. 2017, 8, e2891. [CrossRef]

18. Rubattu, S.; Di Castro, S.; Schulz, H.; Geurts, A.M.; Cotugno, M.; Bianchi, F.; Maatz, H.; Hummel, O.; Falak, S.; Stanzione, R.; et al. Ndufc2 Gene Inhibition Is Associated With Mitochondrial Dysfunction and Increased Stroke Susceptibility in an Animal Model of Complex Human Disease. J. Am. Heart Assoc. 2016, 5, e002701. [CrossRef]

19. Forte, M.; Bianchi, F.; Cotugno, M.; Marchitti, S.; De Falco, E.; Raffa, S.; Stanzione, R.; Di Nonno, F.; Chimenti, I.; Palmerio, S.; et al. Pharmacological restoration of autophagy reduces hypertension-related stroke occurrence. Autophagy 2019, 1-14. [CrossRef]

20. Forte, M.; Palmerio, S.; Bianchi, F.; Volpe, M.; Rubattu, S. Mitochondrial complex I deficiency and cardiovascular diseases: Current evidence and future directions. J. Mol. Med. (Berl.) 2019, 97, 579-591. [CrossRef]

21. Gretarsdottir, S.; Thorleifsson, G.; Manolescu, A.; Styrkarsdottir, U.; Helgadottir, A.; Gschwendtner, A.; Kostulas, K.; Kuhlenbaumer, G.; Bevan, S.; Jonsdottir, T.; et al. Risk variants for atrial fibrillation on chromosome 4q25 associate with ischemic stroke. Ann. Neurol. 2008, 64, 402-409. [CrossRef] [PubMed]

22. Traylor, M.; Farrall, M.; Holliday, E.G.; Sudlow, C.; Hopewell, J.C.; Cheng, Y.C.; Fornage, M.; Ikram, M.A.; Malik, R.; Bevan, S.; et al. Genetic risk factors for ischaemic stroke and its subtypes (the METASTROKE collaboration): A meta-analysis of genome-wide association studies. Lancet Neurol. 2012, 11, 951-962. [CrossRef]

23. Morgado-Pascual, J.L.; Marchant, V.; Rodrigues-Diez, R.; Dolade, N.; Suarez-Alvarez, B.; Kerr, B.; Valdivielso, J.M.; Ruiz-Ortega, M.; Rayego-Mateos, S. Epigenetic Modification Mechanisms Involved in Inflammation and Fibrosis in Renal Pathology. Mediators Inflamm. 2018, 2018, 2931049. [CrossRef] [PubMed]

24. Udali, S.; Guarini, P.; Moruzzi, S.; Choi, S.W.; Friso, S. Cardiovascular epigenetics: From DNA methylation to microRNAs. Mol. Asp. Med. 2013, 34, 883-901. [CrossRef]

25. Heard, E.; Martienssen, R.A. Transgenerational epigenetic inheritance: Myths and mechanisms. Cell 2014, 157, 95-109. [CrossRef]

26. Jones, P.A.; Baylin, S.B. The epigenomics of cancer. Cell 2007, 128, 683-692. [CrossRef]

27. Zhang, W.; Song, M.; Qu, J.; Liu, G.H. Epigenetic Modifications in Cardiovascular Aging and Diseases. Circ. Res. 2018, 123, 773-786. [CrossRef]

28. Jaenisch, R.; Bird, A. Epigenetic regulation of gene expression: How the genome integrates intrinsic and environmental signals. Nat. Genet. 2003, 33, 245-254. [CrossRef]

29. Marmorstein, R.; Roth, S.Y. Histone acetyltransferases: Function, structure, and catalysis. Curr. Opin. Genet. Dev. 2001, 11, 155-161. [CrossRef]

30. Rice, J.C.; Briggs, S.D.; Ueberheide, B.; Barber, C.M.; Shabanowitz, J.; Hunt, D.F.; Shinkai, Y.; Allis, C.D. Histone methyltransferases direct different degrees of methylation to define distinct chromatin domains. Mol. Cell 2003, 12, 1591-1598. [CrossRef]

31. Margueron, R.; Reinberg, D. Chromatin structure and the inheritance of epigenetic information. Nat. Rev. Genet. 2010, 11, 285-296. [CrossRef]

32. Fabian, M.R.; Sonenberg, N.; Filipowicz, W. Regulation of mRNA translation and stability by microRNAs. Ann. Rev. Biochem. 2010, 79, 351-379. [CrossRef]

33. Mattick, J.S.; Makunin, I.V. Non-coding RNA. Hum. Mol. Genet. 2006, 15 (Suppl. 1), R17-R29. [CrossRef]

34. Bartel, D.P. MicroRNAs: Target recognition and regulatory functions. Cell 2009, 136, 215-233. [CrossRef]

35. Wojciechowska, A.; Braniewska, A.; Kozar-Kaminska, K. MicroRNA in cardiovascular biology and disease. Adv. Clin. Exp. Med. 2017, 26, 865-874. [CrossRef] 
36. Chen, X.; Sun, Y.; Cai, R.; Wang, G.; Shu, X.; Pang, W. Long noncoding RNA: Multiple players in gene expression. BMB Rep. 2018, 51, 280-289. [CrossRef]

37. Maass, P.G.; Luft, F.C.; Bahring, S. Long non-coding RNA in health and disease. J. Mol. Med. (Berl.) 2014, 92, 337-346. [CrossRef]

38. Sallam, T.; Sandhu, J.; Tontonoz, P. Long Noncoding RNA Discovery in Cardiovascular Disease: Decoding Form to Function. Circ. Res. 2018, 122, 155-166. [CrossRef]

39. Deng, G.X.; Xu, N.; Huang, Q.; Tan, J.Y.; Zhang, Z.; Li, X.F.; Wei, J.R. Association between promoter DNA methylation and gene expression in the pathogenesis of ischemic stroke. Aging (Albany NY) 2019, 11, 7663-7677. [CrossRef]

40. Tang, J.; Zhuang, S. Histone acetylation and DNA methylation in ischemia/reperfusion injury. Clin. Sci. (Lond.) 2019, 133, 597-609. [CrossRef]

41. Endres, M.; Meisel, A.; Biniszkiewicz, D.; Namura, S.; Prass, K.; Ruscher, K.; Lipski, A.; Jaenisch, R.; Moskowitz, M.A.; Dirnagl, U. DNA methyltransferase contributes to delayed ischemic brain injury. J. Neurosci. 2000, 20, 3175-3181. [CrossRef]

42. Dock, H.; Theodorsson, A.; Theodorsson, E. DNA Methylation Inhibitor Zebularine Confers Stroke Protection in Ischemic Rats. Transl. Stroke Res. 2015, 6, 296-300. [CrossRef]

43. Faraco, G.; Pancani, T.; Formentini, L.; Mascagni, P.; Fossati, G.; Leoni, F.; Moroni, F.; Chiarugi, A. Pharmacological inhibition of histone deacetylases by suberoylanilide hydroxamic acid specifically alters gene expression and reduces ischemic injury in the mouse brain. Mol. Pharmacol. 2006, 70, 1876-1884. [CrossRef]

44. Lee, H.A.; Hong, S.H.; Kim, J.W.; Jang, I.S. Possible involvement of DNA methylation in NKCC1 gene expression during postnatal development and in response to ischemia. J. Neurochem. 2010, 114, 520-529. [CrossRef]

45. Hu, C.J.; Chen, S.D.; Yang, D.I.; Lin, T.N.; Chen, C.M.; Huang, T.H.; Hsu, C.Y. Promoter region methylation and reduced expression of thrombospondin-1 after oxygen-glucose deprivation in murine cerebral endothelial cells. J. Cereb. Blood Flow Metab. 2006, 26, 1519-1526. [CrossRef]

46. van Meurs, J.B.; Pare, G.; Schwartz, S.M.; Hazra, A.; Tanaka, T.; Vermeulen, S.H.; Cotlarciuc, I.; Yuan, X.; Malarstig, A.; Bandinelli, S.; et al. Common genetic loci influencing plasma homocysteine concentrations and their effect on risk of coronary artery disease. Am. J. Clin. Nutr. 2013, 98, 668-676. [CrossRef]

47. Wang, C.; Xu, G.; Wen, Q.; Peng, X.; Chen, H.; Zhang, J.; Xu, S.; Zhang, C.; Zhang, M.; Ma, J.; et al. CBS promoter hypermethylation increases the risk of hypertension and stroke. Clinics (Sao Paulo) 2019, 74, e630. [CrossRef]

48. Yang, Z.; Wang, L.; Zhang, W.; Wang, X.; Zhou, S. Plasma homocysteine involved in methylation and expression of thrombomodulin in cerebral infarction. Biochem. Biophys. Res. Commun. 2016, 473, 1218-1222. [CrossRef]

49. Tziomalos, K.; Athyros, V.G.; Karagiannis, A.; Mikhailidis, D.P. Dyslipidemia as a risk factor for ischemic stroke. Curr. Top. Med. Chem. 2009, 9, 1291-1297. [CrossRef]

50. Imamura, T.; Doi, Y.; Arima, H.; Yonemoto, K.; Hata, J.; Kubo, M.; Tanizaki, Y.; Ibayashi, S.; Iida, M.; Kiyohara, Y. LDL cholesterol and the development of stroke subtypes and coronary heart disease in a general Japanese population: The Hisayama study. Stroke 2009, 40, 382-388. [CrossRef]

51. Tirschwell, D.L.; Smith, N.L.; Heckbert, S.R.; Lemaitre, R.N.; Longstreth, W.T., Jr.; Psaty, B.M. Association of cholesterol with stroke risk varies in stroke subtypes and patient subgroups. Neurology 2004, 63, 1868-1875. [CrossRef]

52. Tanne, D.; Koren-Morag, N.; Graff, E.; Goldbourt, U. Blood lipids and first-ever ischemic stroke/transient ischemic attack in the Bezafibrate Infarction Prevention (BIP) Registry: High triglycerides constitute an independent risk factor. Circulation 2001, 104, 2892-2897. [CrossRef]

53. Wannamethee, S.G.; Shaper, A.G.; Ebrahim, S. HDL-Cholesterol, total cholesterol, and the risk of stroke in middle-aged British men. Stroke 2000, 31, 1882-1888. [CrossRef]

54. Mahley, R.W. Apolipoprotein E: Cholesterol transport protein with expanding role in cell biology. Science 1988, 240, 622-630. [CrossRef]

55. Corder, E.H.; Saunders, A.M.; Strittmatter, W.J.; Schmechel, D.E.; Gaskell, P.C.; Small, G.W.; Roses, A.D.; Haines, J.L.; Pericak-Vance, M.A. Gene dose of apolipoprotein E type 4 allele and the risk of Alzheimer's disease in late onset families. Science 1993, 261, 921-923. [CrossRef] 
56. McCarron, M.O.; Delong, D.; Alberts, M.J. APOE genotype as a risk factor for ischemic cerebrovascular disease: A meta-analysis. Neurology 1999, 53, 1308-1311. [CrossRef]

57. Zhang, H.; Zhao, X.; Wang, C.; Du, R.; Wang, X.; Fu, J.; Sun, Q. A Preliminary Study of the Association between Apolipoprotein E Promoter Methylation and Atherosclerotic Cerebral Infarction. J. Stroke Cerebrovasc. Dis. 2019, 28, 1056-1061. [CrossRef]

58. Zhou, S.; Cai, B.; Zhang, Z.; Zhang, Y.; Wang, L.; Liu, K.; Zhang, H.; Sun, L.; Cai, H.; Lu, G.; et al. CDKN2B Methylation and Aortic Arch Calcification in Patients with Ischemic Stroke. J. Atheroscler. Thromb. 2017, 24, 609-620. [CrossRef]

59. Ridker, P.M. Role of inflammatory biomarkers in prediction of coronary heart disease. Lancet 2001, 358, 946-948. [CrossRef]

60. Malik, I.; Danesh, J.; Whincup, P.; Bhatia, V.; Papacosta, O.; Walker, M.; Lennon, L.; Thomson, A.; Haskard, D. Soluble adhesion molecules and prediction of coronary heart disease: A prospective study and meta-analysis. Lancet 2001, 358, 971-976. [CrossRef]

61. Baccarelli, A.; Tarantini, L.; Wright, R.O.; Bollati, V.; Litonjua, A.A.; Zanobetti, A.; Sparrow, D.; Vokonas, P.S.; Schwartz, J. Repetitive element DNA methylation and circulating endothelial and inflammation markers in the VA normative aging study. Epigenetics 2010, 5, 222-228. [CrossRef] [PubMed]

62. Gallego-Fabrega, C.; Carrera, C.; Reny, J.L.; Fontana, P.; Slowik, A.; Pera, J.; Pezzini, A.; Serrano-Heras, G.; Segura, T.; Marti-Fabregas, J.; et al. TRAF3 Epigenetic Regulation Is Associated With Vascular Recurrence in Patients With Ischemic Stroke. Stroke 2016, 47, 1180-1186. [CrossRef] [PubMed]

63. Gallego-Fabrega, C.; Carrera, C.; Reny, J.L.; Fontana, P.; Slowik, A.; Pera, J.; Pezzini, A.; Serrano-Heras, G.; Segura, T.; Bin Dukhyil, A.A.; et al. PPM1A Methylation Is Associated With Vascular Recurrence in Aspirin-Treated Patients. Stroke 2016, 47, 1926-1929. [CrossRef] [PubMed]

64. Kim, H.J.; Rowe, M.; Ren, M.; Hong, J.S.; Chen, P.S.; Chuang, D.M. Histone deacetylase inhibitors exhibit anti-inflammatory and neuroprotective effects in a rat permanent ischemic model of stroke: Multiple mechanisms of action. J. Pharmacol. Exp. Ther. 2007, 321, 892-901. [CrossRef] [PubMed]

65. Xuan, A.; Long, D.; Li, J.; Ji, W.; Hong, L.; Zhang, M.; Zhang, W. Neuroprotective effects of valproic acid following transient global ischemia in rats. Life Sci. 2012, 90, 463-468. [CrossRef]

66. Ren, M.; Leng, Y.; Jeong, M.; Leeds, P.R.; Chuang, D.M. Valproic acid reduces brain damage induced by transient focal cerebral ischemia in rats: Potential roles of histone deacetylase inhibition and heat shock protein induction. J. Neurochem. 2004, 89, 1358-1367. [CrossRef]

67. Langley, B.; Brochier, C.; Rivieccio, M.A. Targeting histone deacetylases as a multifaceted approach to treat the diverse outcomes of stroke. Stroke 2009, 40, 2899-2905. [CrossRef]

68. Kong, Q.; Hao, Y.; Li, X.; Wang, X.; Ji, B.; Wu, Y. HDAC4 in ischemic stroke: Mechanisms and therapeutic potential. Clin. Epigenet. 2018, 10, 117. [CrossRef]

69. Majdzadeh, N.; Wang, L.; Morrison, B.E.; Bassel-Duby, R.; Olson, E.N.; D’Mello, S.R. HDAC4 inhibits cell-cycle progression and protects neurons from cell death. Dev. Neurobiol. 2008, 68, 1076-1092. [CrossRef]

70. Zhang, Q.Y.; Wang, Z.J.; Sun, D.M.; Wang, Y.; Xu, P.; Wu, W.J.; Liu, X.H.; Zhu, Y.Z. Novel Therapeutic Effects of Leonurine On Ischemic Stroke: New Mechanisms of BBB Integrity. Oxid. Med. Cell. Longev. 2017, 2017, 7150376. [CrossRef]

71. Liu, X.S.; Chopp, M.; Kassis, H.; Jia, L.F.; Hozeska-Solgot, A.; Zhang, R.L.; Chen, C.; Cui, Y.S.; Zhang, Z.G. Valproic acid increases white matter repair and neurogenesis after stroke. Neuroscience 2012, 220, 313-321. [CrossRef] [PubMed]

72. Patnala, R.; Arumugam, T.V.; Gupta, N.; Dheen, S.T. HDAC Inhibitor Sodium Butyrate-Mediated Epigenetic Regulation Enhances Neuroprotective Function of Microglia During Ischemic Stroke. Mol. Neurobiol. 2017, 54, 6391-6411. [CrossRef]

73. Kao, M.H.; Lin, T.N. Histone deacetylases in stroke. Chin. J. Physiol. 2019, 62, 95-107. [CrossRef] [PubMed]

74. Brookes, R.L.; Crichton, S.; Wolfe, C.D.A.; Yi, Q.; Li, L.; Hankey, G.J.; Rothwell, P.M.; Markus, H.S. Sodium Valproate, a Histone Deacetylase Inhibitor, Is Associated With Reduced Stroke Risk After Previous Ischemic Stroke or Transient Ischemic Attack. Stroke 2018, 49, 54-61. [CrossRef] [PubMed]

75. Rink, C.; Khanna, S. MicroRNA in ischemic stroke etiology and pathology. Physiol. Genom. 2011, 43, 521-528. [CrossRef] [PubMed] 
76. Zheng, H.W.; Wang, Y.L.; Lin, J.X.; Li, N.; Zhao, X.Q.; Liu, G.F.; Liu, L.P.; Jiao, Y.; Gu, W.K.; Wang, D.Z.; et al. Circulating MicroRNAs as potential risk biomarkers for hematoma enlargement after intracerebral hemorrhage. CNS Neurosci. Ther. 2012, 18, 1003-1011. [CrossRef]

77. Mirzaei, H.; Momeni, F.; Saadatpour, L.; Sahebkar, A.; Goodarzi, M.; Masoudifar, A.; Kouhpayeh, S.; Salehi, H.; Mirzaei, H.R.; Jaafari, M.R. MicroRNA: Relevance to stroke diagnosis, prognosis, and therapy. J. Cell. Physiol. 2018, 233, 856-865. [CrossRef]

78. Eyileten, C.; Wicik, Z.; De Rosa, S.; Mirowska-Guzel, D.; Soplinska, A.; Indolfi, C.; Jastrzebska-Kurkowska, I.; Czlonkowska, A.; Postula, M. MicroRNAs as Diagnostic and Prognostic Biomarkers in Ischemic Stroke-A Comprehensive Review and Bioinformatic Analysis. Cells 2018, 7, 249. [CrossRef]

79. Laterza, O.F.; Lim, L.; Garrett-Engele, P.W.; Vlasakova, K.; Muniappa, N.; Tanaka, W.K.; Johnson, J.M.; Sina, J.F.; Fare, T.L.; Sistare, F.D.; et al. Plasma MicroRNAs as sensitive and specific biomarkers of tissue injury. Clin. Chem. 2009, 55, 1977-1983. [CrossRef]

80. Dharap, A.; Bowen, K.; Place, R.; Li, L.C.; Vemuganti, R. Transient focal ischemia induces extensive temporal changes in rat cerebral microRNAome. J. Cereb. Blood Flow Metab. 2009, 29, 675-687. [CrossRef]

81. Rubattu, S.; Volpe, M.; Kreutz, R.; Ganten, U.; Ganten, D.; Lindpaintner, K. Chromosomal mapping of quantitative trait loci contributing to stroke in a rat model of complex human disease. Nat. Genet. 1996, 13, 429-434. [CrossRef] [PubMed]

82. Stanzione, R.; Bianchi, F.; Cotugno, M.; Marchitti, S.; Forte, M.; Busceti, C.; Ryskalin, L.; Fornai, F.; Volpe, M.; Rubattu, S. A Decrease of Brain MicroRNA-122 Level Is an Early Marker of Cerebrovascular Disease in the Stroke-Prone Spontaneously Hypertensive Rat. Oxid. Med. Cell Longev. 2017, 2017, 1206420. [CrossRef] [PubMed]

83. Echtay, K.S.; Murphy, M.P.; Smith, R.A.; Talbot, D.A.; Brand, M.D. Superoxide activates mitochondrial uncoupling protein 2 from the matrix side. Studies using targeted antioxidants. J. Biol. Chem. 2002, 277, 47129-47135. [CrossRef] [PubMed]

84. Sekar, D.; Venugopal, B.; Sekar, P.; Ramalingam, K. Role of microRNA 21 in diabetes and associated/related diseases. Gene 2016, 582, 14-18. [CrossRef]

85. Sekar, D.; Shilpa, B.R.; Das, A.J. Relevance of microRNA 21 in Different Types of Hypertension. Curr. Hypertens Rep. 2017, 19, 57. [CrossRef]

86. Jazbutyte, V.; Thum, T. MicroRNA-21: From cancer to cardiovascular disease. Curr. Drug Targets 2010, 11, 926-935. [CrossRef]

87. Xu, L.F.; Wu, Z.P.; Chen, Y.; Zhu, Q.S.; Hamidi, S.; Navab, R. MicroRNA-21 (miR-21) regulates cellular proliferation, invasion, migration, and apoptosis by targeting PTEN, RECK and Bcl-2 in lung squamous carcinoma, Gejiu City, China. PLoS ONE 2014, 9, e103698. [CrossRef]

88. Buller, B.; Liu, X.; Wang, X.; Zhang, R.L.; Zhang, L.; Hozeska-Solgot, A.; Chopp, M.; Zhang, Z.G. MicroRNA-21 protects neurons from ischemic death. FEBS J. 2010, 277, 4299-4307. [CrossRef]

89. Wu, J.; Fan, C.L.; Ma, L.J.; Liu, T.; Wang, C.; Song, J.X.; Lv, Q.S.; Pan, H.; Zhang, C.N.; Wang, J.J. Distinctive expression signatures of serum microRNAs in ischaemic stroke and transient ischaemic attack patients. Thromb. Haemost. 2017, 117, 992-1001. [CrossRef]

90. Tan, K.S.; Armugam, A.; Sepramaniam, S.; Lim, K.Y.; Setyowati, K.D.; Wang, C.W.; Jeyaseelan, K. Expression profile of MicroRNAs in young stroke patients. PLoS ONE 2009, 4, e7689. [CrossRef]

91. Zhao, B.; Zhu, Z.; Hao, J.; Wan, Z.; Guo, X. Decreased plasma miR-335 expression in patients with acute ischemic stroke and its association with calmodulin expression. J. Int. Med. Res. 2016, 44, 1331-1338. [CrossRef] [PubMed]

92. Liu, L.; Yuan, H.; Denton, K.; Li, X.J.; McCullough, L.; Li, J. Calcium/calmodulin-dependent protein kinase kinase beta is neuroprotective in stroke in aged mice. Eur. J. Neurosci. 2016, 44, 2139-2146. [CrossRef] [PubMed]

93. Chen, J.; Yang, T.; Yu, H.; Sun, K.; Shi, Y.; Song, W.; Bai, Y.; Wang, X.; Lou, K.; Song, Y.; et al. A functional variant in the 3'-UTR of angiopoietin-1 might reduce stroke risk by interfering with the binding efficiency of microRNA 211. Hum. Mol. Genet. 2010, 19, 2524-2533. [CrossRef] [PubMed]

94. Papapetropoulos, A.; Garcia-Cardena, G.; Dengler, T.J.; Maisonpierre, P.C.; Yancopoulos, G.D.; Sessa, W.C. Direct actions of angiopoietin-1 on human endothelium: Evidence for network stabilization, cell survival, and interaction with other angiogenic growth factors. Lab. Investig. 1999, 79, 213-223. [PubMed]

95. Suri, C.; Jones, P.F.; Patan, S.; Bartunkova, S.; Maisonpierre, P.C.; Davis, S.; Sato, T.N.; Yancopoulos, G.D. Requisite role of angiopoietin-1, a ligand for the TIE2 receptor, during embryonic angiogenesis. Cell 1996, 87, 1171-1180. [CrossRef] 
96. Stanzione, R.; Sciarretta, S.; Marchitti, S.; Bianchi, F.; Di Castro, S.; Scarpino, S.; Cotugno, M.; Frati, G.; Volpe, M.; Rubattu, S. C2238/alphaANP modulates apolipoprotein E through Egr-1/miR199a in vascular smooth muscle cells in vitro. Cell Death Dis. 2015, 6, e2033. [CrossRef]

97. Dykstra-Aiello, C.; Jickling, G.C.; Ander, B.P.; Shroff, N.; Zhan, X.; Liu, D.; Hull, H.; Orantia, M.; Stamova, B.S.; Sharp, F.R. Altered Expression of Long Noncoding RNAs in Blood After Ischemic Stroke and Proximity to Putative Stroke Risk Loci. Stroke 2016, 47, 2896-2903. [CrossRef]

98. Zhao, F.; Qu, Y.; Liu, J.; Liu, H.; Zhang, L.; Feng, Y.; Wang, H.; Gan, J.; Lu, R.; Mu, D. Microarray Profiling and Co-Expression Network Analysis of LncRNAs and mRNAs in Neonatal Rats Following Hypoxic-ischemic Brain Damage. Sci. Rep. 2015, 5, 13850. [CrossRef]

99. Bao, M.H.; Szeto, V.; Yang, B.B.; Zhu, S.Z.; Sun, H.S.; Feng, Z.P. Long non-coding RNAs in ischemic stroke. Cell Death Dis. 2018, 9, 281. [CrossRef]

100. Chen, R.; Xu, X.; Huang, L.; Zhong, W.; Cui, L. The Regulatory Role of Long Noncoding RNAs in Different Brain Cell Types Involved in Ischemic Stroke. Front. Mol. Neurosci. 2019, 12, 61. [CrossRef]

101. Zhang, B.; Wang, D.; Ji, T.F.; Shi, L.; Yu, J.L. Overexpression of IncRNA ANRIL up-regulates VEGF expression and promotes angiogenesis of diabetes mellitus combined with cerebral infarction by activating NF-kappaB signaling pathway in a rat model. Oncotarget 2017, 8, 17347-17359. [CrossRef] [PubMed]

102. Zhang, X.; Tang, X.; Liu, K.; Hamblin, M.H.; Yin, K.J. Long Noncoding RNA Malat1 Regulates Cerebrovascular Pathologies in Ischemic Stroke. J. Neurosci. 2017, 37, 1797-1806. [CrossRef] [PubMed]

103. Yan, H.; Yuan, J.; Gao, L.; Rao, J.; Hu, J. Long noncoding RNA MEG3 activation of p53 mediates ischemic neuronal death in stroke. Neuroscience 2016, 337, 191-199. [CrossRef] [PubMed]

104. Jung, J.E.; Karatas, H.; Liu, Y.; Yalcin, A.; Montaner, J.; Lo, E.H.; van Leyen, K. STAT-dependent upregulation of 12/15-lipoxygenase contributes to neuronal injury after stroke. J. Cereb. Blood Flow Metab. 2015, 35, 2043-2051. [CrossRef]

105. Liu, X.; Hou, L.; Huang, W.; Gao, Y.; Lv, X.; Tang, J. The Mechanism of Long Non-coding RNA MEG3 for Neurons Apoptosis Caused by Hypoxia: Mediated by miR-181b-12/15-LOX Signaling Pathway. Front. Cell. Neurosci. 2016, 10, 201. [CrossRef]

106. Chen, C.; Cheng, G.; Yang, X.; Li, C.; Shi, R.; Zhao, N. Tanshinol suppresses endothelial cells apoptosis in mice with atherosclerosis via lncRNA TUG1 up-regulating the expression of miR-26a. Am. J. Transl. Res. 2016, 8, 2981-2991.

107. Li, J.; Zhang, M.; An, G.; Ma, Q. LncRNA TUG1 acts as a tumor suppressor in human glioma by promoting cell apoptosis. Exp. Biol. Med. (Maywood) 2016, 241, 644-649. [CrossRef]

108. Chen, S.; Wang, M.; Yang, H.; Mao, L.; He, Q.; Jin, H.; Ye, Z.M.; Luo, X.Y.; Xia, Y.P.; Hu, B. LncRNA TUG1 sponges microRNA-9 to promote neurons apoptosis by up-regulated Bcl2111 under ischemia. Biochem. Biophys. Res. Commun. 2017, 485, 167-173. [CrossRef]

109. Zhu, W.; Tian, L.; Yue, X.; Liu, J.; Fu, Y.; Yan, Y. LncRNA Expression Profiling of Ischemic Stroke During the Transition From the Acute to Subacute Stage. Front. Neurol. 2019, 10, 36. [CrossRef]

110. Tang, Y.; Lin, Y.H.; Ni, H.Y.; Dong, J.; Yuan, H.J.; Zhang, Y.; Liang, H.Y.; Yao, M.C.; Zhou, Q.G.; Wu, H.Y.; et al. Inhibiting Histone Deacetylase 2 (HDAC2) Promotes Functional Recovery From Stroke. J. Am. Heart Assoc. 2017, 6. [CrossRef]

111. Santini, V.; Melnick, A.; Maciejewski, J.P.; Duprez, E.; Nervi, C.; Cocco, L.; Ford, K.G.; Mufti, G. Epigenetics in focus: Pathogenesis of myelodysplastic syndromes and the role of hypomethylating agents. Crit. Rev. Oncol. Hematol. 2013, 88, 231-245. [CrossRef] [PubMed]

112. Yang, X.; Tang, X.; Sun, P.; Shi, Y.; Liu, K.; Hassan, S.H.; Stetler, R.A.; Chen, J.; Yin, K.J. MicroRNA-15a/16-1 Antagomir Ameliorates Ischemic Brain Injury in Experimental Stroke. Stroke 2017, 48, 1941-1947. [CrossRef] [PubMed]

113. Mallick, B. AGO-Driven Non-Coding RNAs: Codes to Decode the Therapeutics of Diseases, 1st ed.; Elsevier: Amsterdam, The Netherlands, 2019; ISBN 9780128156698.

(C) 2020 by the authors. Licensee MDPI, Basel, Switzerland. This article is an open access article distributed under the terms and conditions of the Creative Commons Attribution (CC BY) license (http://creativecommons.org/licenses/by/4.0/). 